\title{
The strength of density-dependent mortality is contingent on climate and seedling size
}

\author{
Xiaoyang Song $^{1}$ (D) | Daniel J. Johnson ${ }^{2}$ | Min Cao ${ }^{1}$ | Maria Natalia Umaña ${ }^{3,4}$ \\ Xiaobao Deng ${ }^{1}$ | Xiaofei Yang ${ }^{1}$ | Wenfu Zhang ${ }^{1}$ | Jie Yang ${ }^{1}$ (D)
}

${ }^{1}$ Key Laboratory of Tropical Forest Ecology, Xishuangbanna Tropical Botanical Garden, Chinese Academy of Sciences, Mengla, Yunnan, China

${ }^{2}$ Earth and Environmental Sciences, Los Alamos National Lab, Los Alamos, New Mexico

${ }^{3}$ Yale School of Forestry and Environmental Studies, New Haven, Connecticut

${ }^{4}$ Department of Ecology and Evolutionary Biology, University of Michigan, Ann Arbor, Michigan

\section{Correspondence}

Jie Yang, Key Laboratory of Tropical Forest Ecology, Xishuangbanna Tropical Botanical Garden, Chinese Academy of Sciences, 666303, Mengla, Yunnan, China.

Email: yangjie@xtbg.org.cn

\section{Funding information}

National Natural Science Foundation of China, Grant/Award Number: 31400362 and 31670442; National Key Basic Research Program of China, Grant/Award Number: 2014CB954100; West Light Foundation of the Chinese Academy of Sciences; Youth Innovation Promotion Association of the Chinese Academy of Sciences, Grant/Award Number: 2016352; Applied Fundamental Research Foundation of Yunnan Province, Grant/Award Number: 2014GA003; CAS 135 programme, Grant/Award Number: 2017XTBG-T01

Co-ordinating Editor: Beverly Collins

\begin{abstract}
Questions: Density-dependent processes may promote species diversity in plant communities. Here, we tested whether seedling survival was density-dependent and varied by seedling size, species and climatic factors.

Location: Tropical rain forest, Xishuangbanna, southwest China.

Methods: Generalized linear mixed-effects models were used to examine seedling survival (232 tree species) across 9 years of seedling census data from a 20 -ha tropical forest dynamics plot. Our predictor variables were conspecific and heterospecific neighbour density, size of the seedling and annual variation in climatic factors.

Results: We found significant negative effects of conspecific tree density, but positive effects of heterospecific seedling density on the survival of tree seedlings in this plot. In general, conspecific negative density dependence (CNDD) was observed most frequently for large size classes of seedlings ( $\geq 20-\mathrm{cm}$ high), while heterospecific positive density dependence (HPDD) was similar at all size classes. CNDD for large seedlings was stronger during warm years, and HPDD for large seedlings was stronger during dry years.

Conclusions: Our study suggests that the strength of density dependence varied through time, and this strength was influenced by water availability and temperature. Our results highlight the potential for changes in species composition and species co-existence that could result from increasing temperature-strengthening CNDD effects and decreasing precipitation strengthening HPDD effects.
\end{abstract}

\section{KEYWORDS}

competition, density dependence, Janzen-Connell hypothesis, mixed models, neighbour effect, precipitation, seedling, temperature

\section{1 | INTRODUCTION}

One of the most important mechanisms promoting species diversity is negative density-dependent (NDD) mortality (LaManna, Walton, Turner, \& Myers, 2016; LaManna et al., 2017; Wright, 2002). Such processes reduce seedling survival when higher densities of conspecific neighbours surround them. Conversely, the survival of individuals increases with declining density of conspecific trees, affording establishment opportunities for other species' seedlings near species experiencing strong density-dependent mortality (Connell, 1978; Harms, Wright, Calderon, Hernandez, \& Herre, 2000; Janzen, 1970; Johnson, Beaulieu, Bever, \& Clay, 2012). The fluctuations in weather can alter community assembly (Gornish \& Tylianakis, 2013) and inter- and intra-annual weather variability has been found to have some connection with the strength of densitydependent mortality (Bachelot, Kobe, \& Vriesendorp, 2015; Hersh, 
Vilgalys, \& Clark, 2011; Lin, Comita, Zheng, \& Cao, 2012; Yanar, Lipps, \& Deep, 1997).

Among the main mechanisms driving NDD mortality at early ontogenetic stages are resource competition from conspecific neighbours (Stoll \& Newberry, 2005) and natural enemies and pathogen attacks (Clark \& Clark, 1985). Moreover, previous studies showed that the strength of conspecific negative density dependence (CNDD) showed significant seasonal and annual variability (Lin et al., 2012; Wu et al., 2016). For instance, in a tropical seasonal rain forest in southwest China, the dry season showed stronger CNDD mortality than the rainy season, which indicates that water availability might influence CNDD processes (Lin et al., 2012). Another study, in Costa Rican tropical forest, showed that common species had higher CNDD than rare species in warmer and wetter years (Bachelot et al., 2015). To date, the factors that drive the temporal dynamics of CNDD effects are poorly understood. Especially in the context of global change, understanding the effects of changing climate on the mechanisms that influence species co-existence is critical to making informed forecasts of forest response in the future (Valladares, Bastias, Godoy, Granda, \& Escudero, 2015).

Climatic conditions, in particular those associated with water availability, have the potential to play a key role in driving community dynamics linked with NDD processes in tropical rain forests. It has been hypothesized that increased temperature and precipitation could enhance activities of pathogens and herbivore insects (Brenes-Arguedas, Coley, \& Kursar, 2009; Swinfield, Lewis, Bagchi, \& Freckleton, 2012), ultimately leading to stronger CNDD effects. Bunker and Carson (2005) suggested that declines in annual precipitation weaken NDD in a seasonal forest in Panama. However, Lin et al. (2012) suggested that dry periods might increase water limitation and enhance intra-specific competition, which results in stronger CNDD effects during dry periods.

In addition to the negative effects on conspecifics, previous studies have shown that heterospecific neighbours tend to have positive density-dependent effects on seedling survival (Comita \& Hubbell, 2009; Johnson et al., 2014; Lu et al., 2015). This effect could be explained as a result of the "species herd protection hypothesis", which suggests that the increase of heterospecific density can decrease encounters between pests and pathogens and their preferred (or most susceptible) hosts, which in turn increases the survival rate of rare hosts (Peters, 2003). Moreover, the strength of protection may fluctuate with the density of pests and pathogens (Dobson 2004; Bagchi et al., 2014; Spear, Coley, \& Kursar, 2015; Xu, Wang, Liu, Zhang, \& Yu, 2015). The density of pests and pathogens is likely to rapidly increase potential outbreak levels when host density is high, resulting in high rates of mortality and driving evolutionary selection (Bagchi et al., 2010; Clay et al., 2008). As masting events tend to be correlated with environmental conditions, density-dependent processes may be linked to weather patterns (Jia, Dai, Shen, Zhang, \& Wang, 2011; Zhang, Wang, \& Yu, 2014). Inter-specific interactions can also produce positive density-dependent effects by facilitating survival of heterospecific seedlings through alteration of the habitat (Bertness \& Callaway, 1994; Jia et al., 2011; Zhang et al., 2014).

Besides the effect of temperature and precipitation on the strength of NDD, seedling age (size) is an additional factor that impacts seedling demography (Metz, Sousa, \& Valencia, 2010; Record, Kobe, Vriesendorp, \& Finley, 2016; Zhu, Comita, Hubbell, \& Ma, 2015). NDD can be stronger in the earlier life stages of plants (Comita et al., 2014; Zhu et al., 2015), potentially because seedlings lack defences and resistance capacities; thus, they are more easily attacked by natural enemies. On the other hand, CNDD may increase with seedling age because of the accumulation of a specific pathogen and increasing asymmetric conspecific resource competition from conspecific trees (Benitez, Hersh, Vilgalys, \& Clark, 2013; Lin et al., 2012; Liu et al., 2012). The increased NDD effect with size may promote diversity by enhancing the establishment of heterospecific species.

Here, we tested whether variation in density dependence was explained by environmental factors. In addition, we tested whether relationships exhibited size dependence. In particular, we focus on the following questions: (a) how does climate affect the strength of density-dependent processes on seedling survival; (b) does climate affect the strength of conspecific and heterospecific density dependence for seedlings; and (c) does the role of climate in density-dependent responses vary with seedling size?

\section{2 | METHODS}

\section{1 | Study site}

The study plot is located in Xishuangbanna, southwest China $\left(101^{\circ} 34^{\prime} \mathrm{E}, 21^{\circ} 36^{\prime} \mathrm{N}\right.$; Figure 1$)$. This region is strongly affected by a monsoon climate, with distinct rainy and dry seasons. Mean annual temperature and rainfall of this region are, respectively, $21.8^{\circ} \mathrm{C}$ and $1,493 \mathrm{~mm}$. The majority of rainfall (about $80 \%$ of annual rainfall) occurs in the wet season between May and October (Cao, Zou, Warren, \& Zhu, 2006). The 20-ha Xishuangbanna forest dynamics plot $(400 \mathrm{~m} \times 500 \mathrm{~m})$ was established in 2007 , following the protocol of Condit (1998), where all freestanding trees, $\geq 1 \mathrm{~cm}$ DBH were tagged and identified to species (Condit, 1998).

In Nov 2007, we established 150 seed trap stations (a 0.5- $\mathrm{m}^{2}$ seed trap with three $1-\mathrm{m}^{2}$ seedling plots) stratified randomly in the plot to monitor seed rain and seedling dynamics (Figure 1). Three seedling plots were placed $2 \mathrm{~m}$ away from the sides of the seed trap. In each seedling plot, woody plants $<1 \mathrm{~cm}$ DBH were defined as seedlings, and were tagged and identified. Height of the seedlings was measured from the ground to the apical bud. The first seedling survey was carried out in Nov 2007. We conducted subsequent surveys in November of the following years. In this study, we analysed the seedling data collected from 2007 to 2015, excluding 25 unidentified seedlings (Supporting information Appendix S1). 


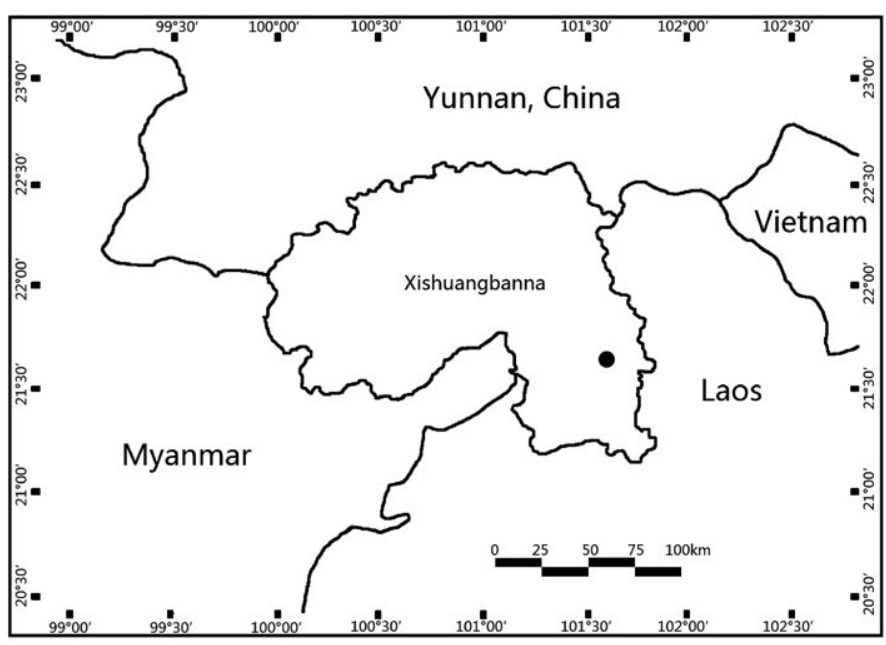

8

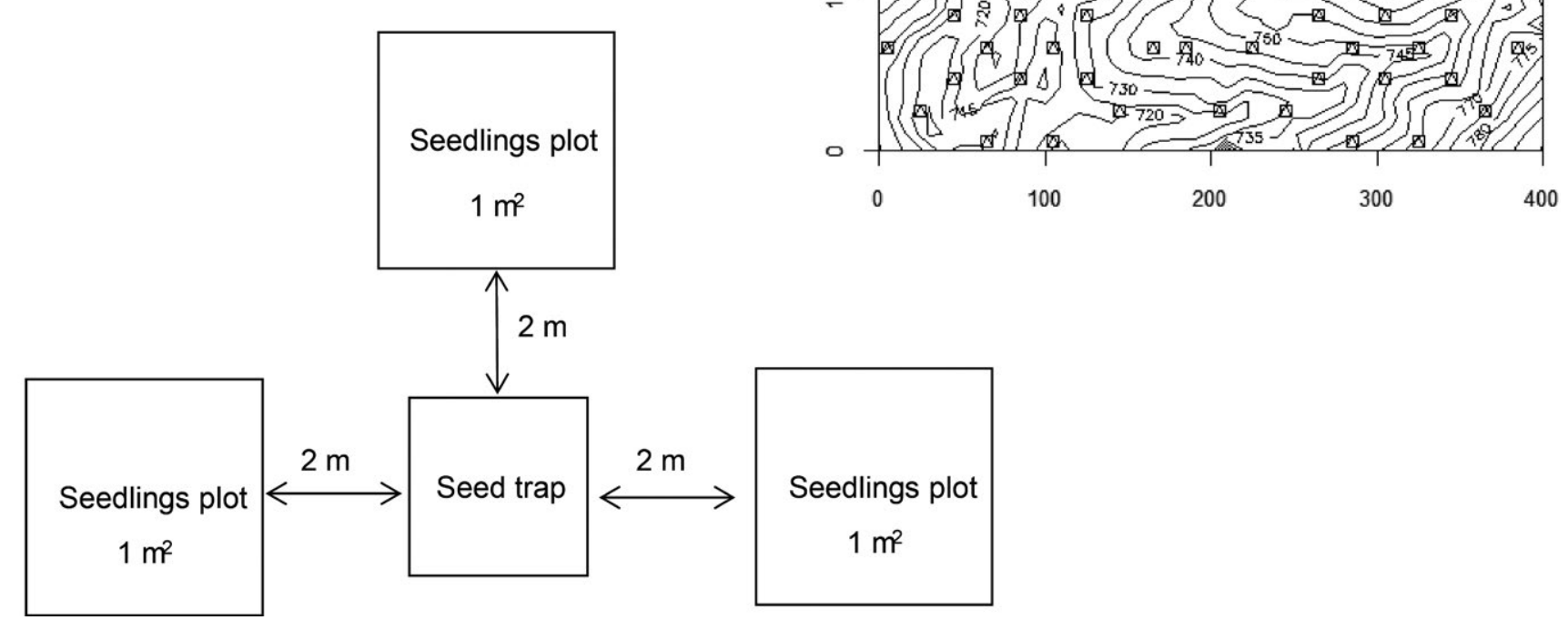

FIGURE 1 Location and map of the 20-ha plot and the components of each seed trap station. The locations of the 150 seed trap stations are represent by squares. The three $1-\mathrm{m}^{2}$ seedling plots were $2 \mathrm{~m}$ away from the seed trap

\section{2 | Climate data}

The monthly record of air temperature and precipitation was collected at the meteorological station of Xishuangbanna Station for Tropical Rain Forest Ecosystem Studies of Xishuangbanna Tropical Botanical Garden. This station is $47.4 \mathrm{~km}$ away from the Xishaungbanna forest dynamic plot. We calculated average monthly temperature and total precipitation from November to October of the following year as the annual mean monthly temperature and annual precipitation.

\section{3 | Density calculations}

Four density variables were calculated to estimate the neighbourhood effects. We calculated the density of conspecific $\left(\right.$ Den $\left._{\text {con }}\right)$ and heterospecific $\left(\right.$ Den $\left._{\text {het }}\right)$ seedling neighbours for the focal seedling within the $1-\mathrm{m}^{2}$ seedling plots for each year (Figure 1).

We calculated the total basal area of conspecific $\left(B A_{c o n}\right)$ and heterospecific $\left(B A_{\text {het }}\right)$ trees found within a $20-\mathrm{m}$ radius of each seed trap. We divided the basal area of each tree by the distance between the tree and the centre of the seed trap (DISTANCE):

$$
B A_{\text {con }} \text { or } B A_{\text {het }}=\sum_{i}^{N}\left(B_{i} / \text { DISTANCE }_{i}\right)
$$

where $i$ is a conspecific or heterospecific tree individual found within the $20-\mathrm{m}$ radius. $\mathrm{A} 20-\mathrm{m}$ radius was assigned following a previous study in this plot (Wu et al., 2016), which indicated that $20 \mathrm{~m}$ had stronger support than other scales (10 and $30 \mathrm{~m}$ ). As a result, data from 66 of the 450 seedling plots were excluded from the following analyses because these seedling plots were within $20 \mathrm{~m}$ of the edge of the plot.

\subsection{Statistical analysis}

We divided the response variable (probability of seedling survival) into three size categories based on seedling height, i.e. all seedlings, small seedlings (height $<20 \mathrm{~cm}$ ) and large seedlings 


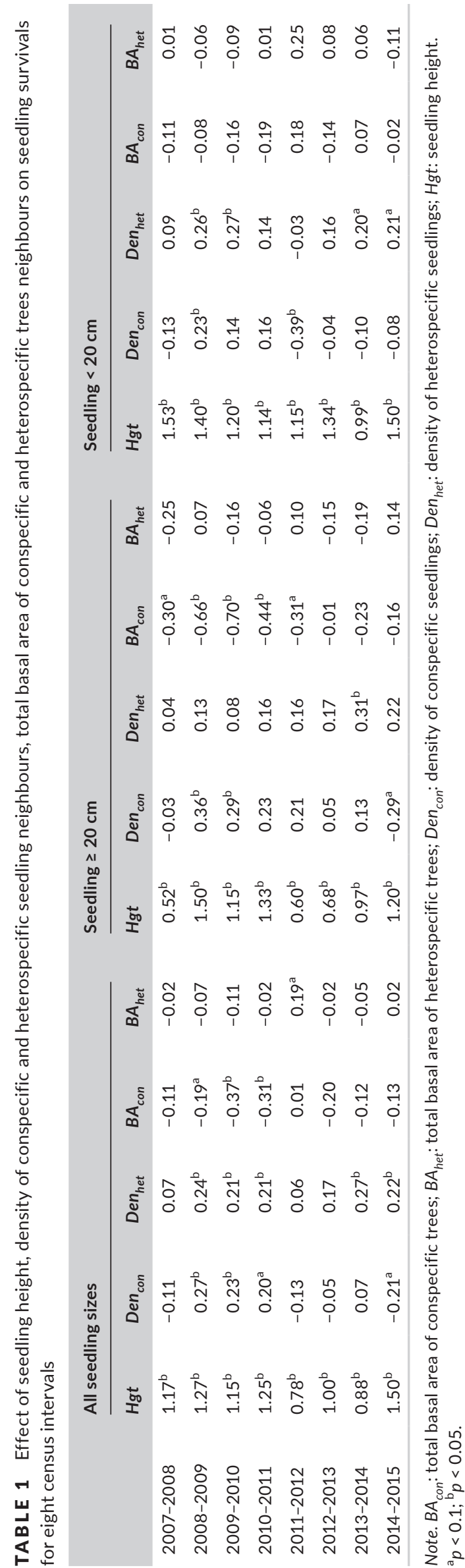

(height $\geq 20 \mathrm{~cm}$; Lin et al., 2012; Wu et al., 2016). The annual (from November to November of the next year) survival probability of seedlings was modelled using GLMMs with binominal error distribution. Binomial response variable was used to show whether individual seedlings were alive (given 1 ) or dead (0). The explanatory variables were seedling height (log-transformed), which showed a significant correlation with its survivorship in previous studies (Lin et al., 2012; Wu et al., 2016), density of conspecific $\left(B A_{\text {con }}\right)$ and heterospecific $\left(B A_{\text {het }}\right)$ adult neighbours, and density of conspecific $\left(\right.$ Den $\left._{\text {con }}\right)$ and heterospecific $\left(\right.$ Den $\left._{\text {het }}\right)$ seedlings. We standardized continuous explanatory variables (including log-transformed seedling height) by subtracting their mean values and dividing by their SD before analyses to allow for comparisons among parameter estimates. Three seedling plots were nested within a sampling point, and we assigned this as a random effect in the GLMMs. Species identity was also incorporated into the model as a cross random effect to account for the inter-specific variations of survival probabilities.

Statistical models were developed with all density variables as fixed effects. First, we estimated the relative effects of all factors on the survival of seedling at community level. Then, we used linear regression models to test whether conspecific adult density-dependent effects and heterospecific seedling density-dependent effects of all seedlings, small seedlings and large seedlings correlated with annual mean temperature or annual precipitation. We also tested whether conspecific adult density-dependent effects and heterospecific seedling densitydependent effects vary between seedling size classes. We used the Shapiro-Wilk test to test if the data are normally distributed and Bartlett's test to examine whether the variances in each of the groups are the same. Then, we used a t-test to determine if the coefficient values of two density parameters had significant differences between size classes.

We conducted all analyses in R 3.0.3 (R Foundation for Statistical Computing, Vienna, Austria). We use the glmer function with the recommended Laplace method (Bolker et al., 2009) of the Ime4 package to fit the GLMM.

\section{3 | RESULTS}

Densities of conspecific and heterospecific neighbours had both significant negative and positive impacts on seedling survival, depending on size class and year (Table 1). Conspecific seedling density showed both significant positive and negative effects on seedling survival in all seedlings pooled, as well as small $(<20-\mathrm{cm}$ high) and large ( $\geq 20-\mathrm{cm}$ high) seedlings, and these effects varied from year to year. Conspecific adult density had significant negative effects on survival of seedlings in all seedlings ( 3 of 8 years) and large seedlings ( 5 of 8 years). We found positive density-dependent survival related to heterospecific seedling density in all size classes $(5$ of 8 years for all seedlings, 1 of 8 years for large seedlings and 4 of 8 years for small seedlings). We found no significant effect of heterospecific 


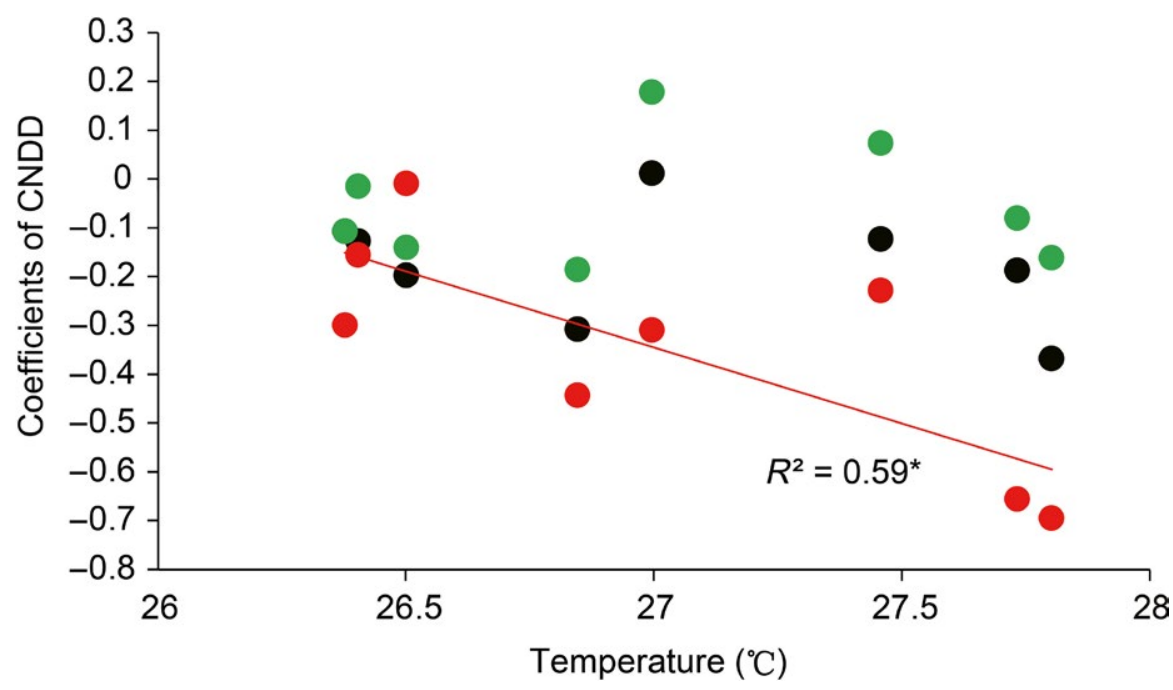

FIGURE 2 Relationship between estimates of adult conspecific adult density-dependent (CNDD) and annual mean temperature (black points refer to all seedlings; red points and line refer to large seedlings; green points refer to small seedlings; ${ }^{*} p<0.05$ ) [Colour figure can be viewed at wileyonlinelibrary.com]

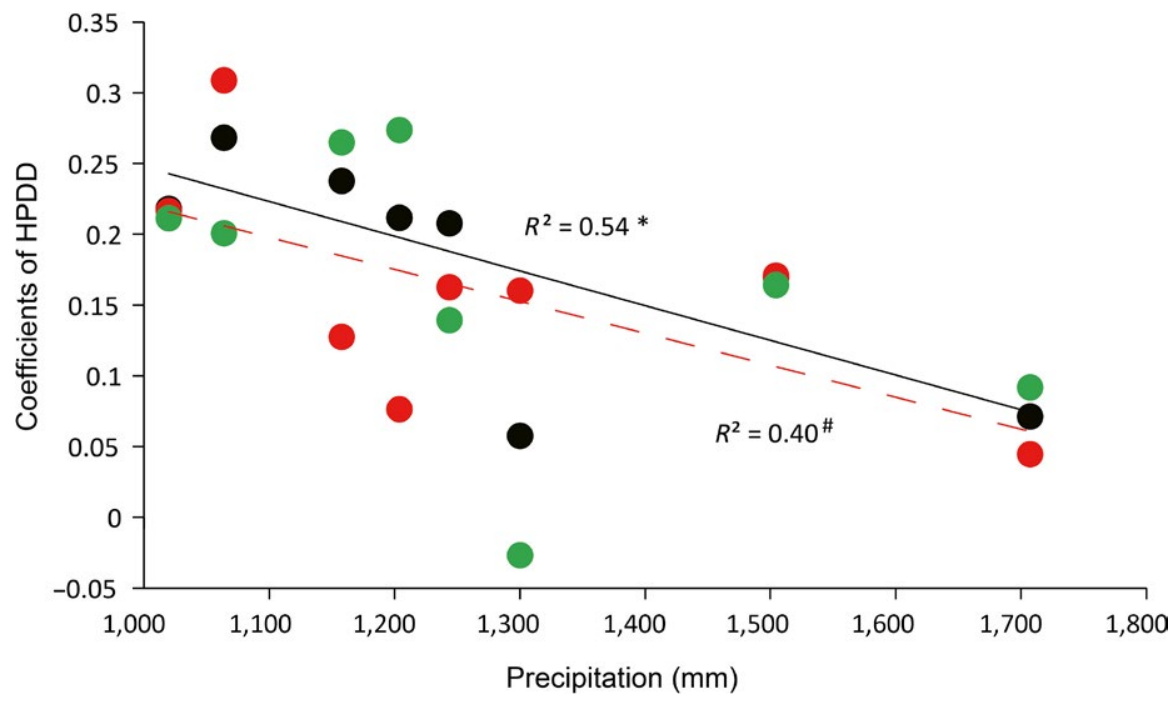

FIGURE 3 Relationship between estimates of heterospecific seedling density dependence (HPDD) and annual precipitation (black points and line refer to all seedlings; red points and line refer to large seedlings; green points refer to small seedlings; ${ }^{\#} p<0.1 ;{ }^{*} p<0.05$ ) [Colour figure can be viewed at wileyonlinelibrary. com]

tree density on seedling survival in any size class (all seedlings, large seedlings and small seedlings).

Both conspecific and heterospecific density effects were correlated with climatic factors. Conspecific adult density-dependent effects on survival of large seedlings were significantly correlated with annual mean temperature $\left(R^{2}=0.59, p=0.02\right)$; however, conspecific adult density-dependent effects on survival of all seedlings and small seedlings were not significantly correlated with annual mean temperature (Figure 2). Effects of heterospecific seedling density on seedling survival of all seedling size classes were correlated with annual precipitation $\left(R^{2}=0.54, p=0.04\right)$, as well as large seedlings $\left(R^{2}=0.40, p=0.09\right)$, but heterospecific seedling density-dependent effects of small seedlings were not significantly correlated with annual precipitation (Figure 3).

There was large variation in conspecific adult density-dependent effects, but small variation in heterospecific seedling densitydependent effects among seedling size classes (Table 1). Large seedlings tended to suffer more seedling mortality due to CNDD of an adult tree neighbour than small seedlings ( $t=3.10, p=0.01$;
Figure 4). In contrast, the strength of heterospecific seedling density-dependent mortality did not differ between seedling size classes (Figure 5).

\section{DISCUSSION}

Density dependence effects help drive seedling survival dynamics in tropical forest communities. In this study, we were interested in examining the role of temporal climatic variation (temperature and precipitation) and seedling size on the strength of densitydependent survival. Our results show that the strength of CNDD of large seedlings ( $\geq 20-\mathrm{cm}$ high) is strongly dependent on annual variation in temperature. Furthermore, we found that the strength of heterospecific density dependence also varies with climatic conditions, specifically precipitation, indicating that neighbouring tree identity influences community dynamics, depending on weather conditions. Further, we found that the strength of density dependence is size-dependent. 


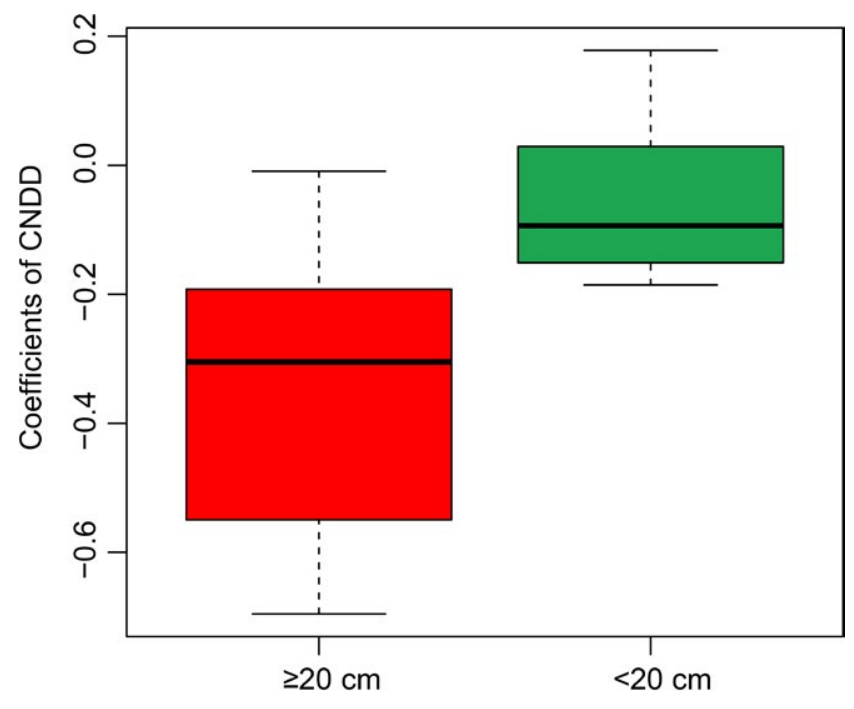

FIGURE 4 Estimates of conspecific adult density dependence for large seedlings (red) and small seedlings (green). Error bars represent $S E(t=3.10, p=0.01)$ [Colour figure can be viewed at wileyonlinelibrary.com]

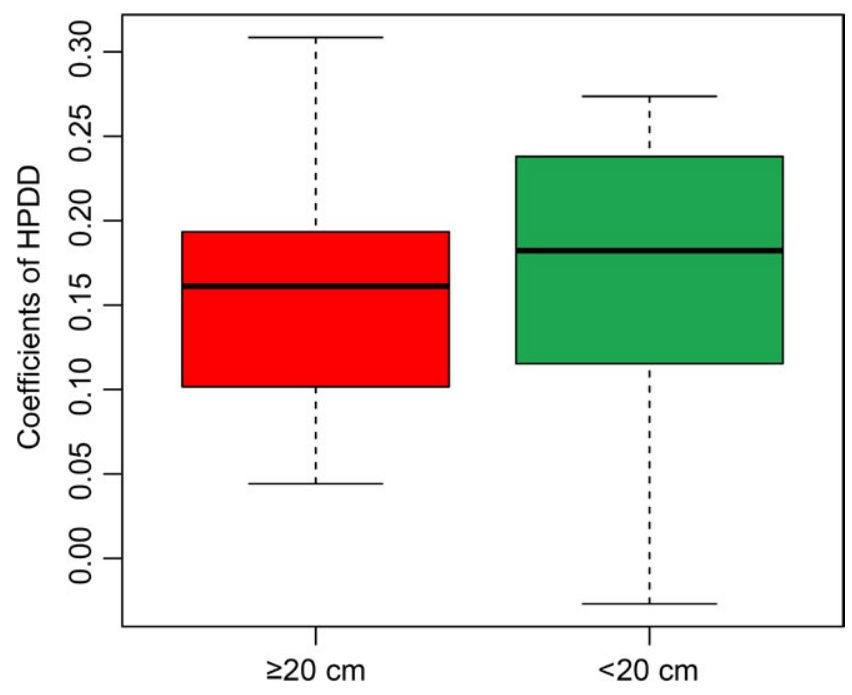

FIGURE 5 Estimates of heterospecific seedling density dependence for large seedlings (red) and small seedlings (green). Error bars represent $S E(t=0.14, p=0.89)$ [Colour figure can be viewed at wileyonlinelibrary.com]

\section{1 | Conspecific NDD variation and climatic condition}

Seeding mortality was both positively and negatively related to conspecific seedling density, depending on the year (Table 1). NDD mortality is common during the seedling stage of tree species (Comita et al., 2014). A previous study indicated that CNDD related to seedling density was easily detected when large recruitment events occurred (Metz et al., 2010), which are often related to climatic cues. However, previous studies indicated that the negative effects of conspecific seedling density could be overwhelmed by the habitat effect (Comita \& Hubbell, 2009). Thus, the positive effect of conspecific seedling density could be an indication that seedling survival may benefit from habitat preference (Valencia et al., 2004).

To date, few studies have found clear relationships between the strength of NDD and temporal variability in climatic conditions (Bachelot et al., 2015; Lin et al., 2012). Compared to other studies, our study used a long-term time series data set, which may have increased our ability to detect this correlation. We found evidence that the CNDD was strongly related to mean annual temperature (Figure 2). Increasing temperature generally accelerates the metabolism of seedlings, and larger seedlings tend to have higher demand for resources during warm periods, which might increase mortality through intra-specific competition. Alternately, warmer years may benefit pathogen populations, leading to a similar result. This is an area that should receive more research attention in the future.

In a Costa Rican tropical wet forest, the strength of CNDD was enhanced by both increasing temperature and precipitation (Bachelot et al., 2015). However, in our study, precipitation was not correlated to CNDD. Declining precipitation can cause high conspecific competition for water resources because conspecifics access water in similar ways (Meinzer et al., 1999), which could result in increasing CNDD. But declining precipitation can result in drought and create unsuitable conditions for pests and pathogens (Coley \& Barone, 1996), which could result in decreasing CNDD. Thus, increased competition from conspecific tree neighbours may be balanced by decreased natural enemy attacks. Future studies should focus on disentangling the effects of climate on competition and natural enemy populations to advance our understanding of the controls on forest community composition.

\section{2 | Heterospecific positive density-dependent variation and climate}

We found positive density dependence of heterospecific seedling neighbours (Figure 5); the survival of target seedlings was higher when surrounded by a higher number of heterospecific neighbours. This may be because the high proportion of heterospecific neighbours decreased intra-specific competition. Our result is also consistent with studies in another tropical forest (Comita \& Hubbell, 2009), which could be explained by the "species herd protection hypothesis" (Peters, 2003). This hypothesis assumes increased heterospecific crowding decreases the probability of a host encountering its pests and pathogens. As a result, seedling survival is likely to be lower in an area of high conspecific tree neighbour density and higher in an area with many heterospecific tree neighbours. The heterospecific positive density dependence (HPDD) could also be caused by niche partitioning among species, which reduces competitive exclusion compared to conspecifics (Vandermeer, 1972). Moreover, heterospecific neighbours may have positive effects on the performance of seedlings by facilitating beneficial microenvironments (Bruno, Stachowicz, \& Bertness, 2003).

The positive heterospecific density-dependent effects may also indicate that conditions of the site, such as light resource, water 
availability and soil characters, have a positive influence on seedling survivorship (Bai et al., 2012; Comita \& Engelbrecht, 2009; Comita \& Hubbell, 2009; Piao, Comita, Jin, \& Kim, 2013). A previous study in this region has also shown that the edaphic and topographic variables had important effects on seedling survival (Wu et al., 2016). In this study, we found that positive heterospecific density dependence was consistent between seedling size classes (Figure 5), and the effect was increased with decreasing precipitation (Figure 3). Positive interactions among different plant species can increase with abiotic stress (Callaway et al., 2002). Our study suggests that water-limiting conditions could increase the facilitation process among individuals of different species and might enhance the positive effect caused by the "herd protection" process.

\section{3 | Size-dependent density dependence}

We found that CNDD effects were stronger in large seedlings than small seedlings (Figure 4). The strength of CNDD also changed across size classes in other forests (Comita et al., 2014; Zhu et al., 2015). Our result, however, showed that the larger seedlings suffered stronger CNDD from trees than the smaller seedlings. The increased NDD effect with seedling size might be driven by accumulation of a specific pathogen or increasing asymmetric conspecific resource competition (Benitez et al., 2013; Lin et al., 2012; Liu et al., 2012). However, small seedlings were easily damaged by changes in environmental conditions during a study in Panama (Engelbrecht, Kursar, \& Tyree, 2005). A study in lowland Amazonian rain forest found opposite results, the density of conspecific seedlings had strong negative effects on the survival of first-year seedlings (Metz et al., 2010). Our results suggested that the seedling-seedling interaction might be weak in this tropical forest. Further studies should examine different mechanisms (e.g. intra-specific competition or negative plant-soil feedback) on the generality of these processes.

\subsection{Implications for predicting the response of seedlings to climate change}

In the context of global climate change, the effect of climate on the mechanisms promoting species diversity should be given more attention (Valladares et al., 2015), since changing climatic conditions may alter competition and facilitation processes and ultimately affect patterns of species richness and diversity (Gornish \& Tylianakis, 2013). Previous studies suggested that high species diversity loss might occur in tropical areas if drought conditions increase, because most tropical tree species are drought-sensitive (Slik, 2004; Slot \& Poorter, 2007). In our study region, during the last 40 years, annual temperatures have increased, while evapotranspiration rates and relative humidity have decreased (Fan, Bräuning, Thomas, Li, \& Cao, 2011; Fan \& Thomas, 2013). Based on our findings, we suggest that increased temperature and drought may increase the strength of both negative conspecific and positive heterospecific densitydependent effects, which may promote species co-existence to a certain extent.
In summary, we found strong evidence that density-dependent seedling survival is strongly influenced by climatic variables. The strength of these effects is size-dependent and strongly influenced by annual precipitation and annual mean temperature. Our results highlight the importance of evaluating long-term data in the framework of climatic changes.

\section{ACKNOWLEDGEMENTS}

This research was supported by the National Natural Science Foundation of China (31400362 and 31670442), National Key Basic Research Program of China (2014CB954100), the West Light Foundation of the Chinese Academy of Sciences, Youth Innovation Promotion Association of the Chinese Academy of Sciences (2016352), the Applied Fundamental Research Foundation of Yunnan Province (2014GA003) and the CAS 135 programme (No. 2017XTBG-T01). We also acknowledge the Center for Tropical Forest Science (Forest-GEO), and this work benefited from ForestGEO workshops (NSF DEB-1046113 to S.J. Davies). We thank Xishuangbanna Station for Tropical Rain Forest Ecosystem Studies of Xishuangbanna Tropical Botanical Garden for assistance with the fieldwork. We also thank four anonymous reviewers for valuable comments that helped improve this manuscript.

\section{ORCID}

Xiaoyang Song (iD http://orcid.org/0000-0001-9529-1418

Maria Natalia Umaña (iD http://orcid.org/0000-0001-5876-7720

Jie Yang (iD http://orcid.org/0000-0002-4444-8240

\section{REFERENCES}

Bachelot, B., Kobe, R. K., \& Vriesendorp, C. (2015). Negative densitydependent mortality varies over time in a wet tropical forest, advantaging rare species, common species, or no species. Oecologia, 179, 853-861. https://doi.org/10.1007/s00442-015-3402-7

Bagchi, R., Gallery, R. E., Gripenberg, S., Gurr, S. J., Narayan, L., Addis, C. E., ... Lewis, O. T. (2014). Pathogens and insect herbivores drive rainforest plant diversity and composition. Nature, 506, 85-88. https:// doi.org/10.1038/nature12911

Bagchi, R., Swinfield, T., Gallery, R. E., Lewis, O. T., Gripenberg, S., Narayan, L., \& Freckleton, R. P. (2010). Testing the Janzen-Connell mechanism: Pathogens cause overcompensating density dependence in a tropical tree. Ecology Letters, 13, 1262-1269. https://doi. org/10.1111/j.1461-0248.2010.01520.x

Bai, X. J., Queenborough, S. A., Wang, X. G., Zhang, J., Li, B. H., Yuan, Z. Q., ... Hao, Z. Q. (2012). Effects of local biotic neighbors and habitat heterogeneity on tree and shrub seedling survival in an old-growth temperate forest. Oecologia, 170, 755-765. https://doi.org/10.1007/ s00442-012-2348-2

Benitez, M.-S., Hersh, M. H., Vilgalys, R., \& Clark, J. S. (2013). Pathogen regulation of plant diversity via effective specialization. Trends in Ecology \& Evolution, 28, 705-711. https://doi.org/10.1016/j. tree.2013.09.005

Bertness, M. D., \& Callaway, R. (1994). Positive interactions in communities. Trends in Ecology \& Evolution, 9, 191-193. https://doi. org/10.1016/0169-5347(94)90088-4 
Bolker, B. M., Brooks, M. E., Clark, C. J., Geange, S. W., Poulsen, J. R., Stevens, M. H. H., \& White, J. S. S. (2009). Generalized linear mixed models: A practical guide for ecology and evolution. Trends in Ecology \&Evolution, 24, 127-135. https://doi.org/10.1016/j.tree.2008.10.008

Brenes-Arguedas, T., Coley, P. D., \& Kursar, T. A. (2009). Pests vs. drought as determinants of plant distribution along a tropical rainfall gradient. Ecology, 90, 1751-1761. https://doi.org/10.1890/08-1271.1

Bruno, J. F., Stachowicz, J. J., \& Bertness, M. D. (2003). Inclusion of facilitation into ecological theory. Trends in Ecology \& Evolution, 18, 119125. https://doi.org/10.1016/S0169-5347(02)00045-9

Bunker, D. E., \& Carson, W. P. (2005). Drought stress and tropical forest woody seedlings: Effect on community structure and composition. Journal of Ecology, 93, 794-806. https://doi. org/10.1111/j.1365-2745.2005.01019.x

Callaway, R. M., Brooker, R. W., Choler, P., Kikvidze, Z., Lortie, C. J., Michalet, R., ... Cook, B. J. (2002). Positive interactions among alpine plants increase with stress. Nature, 417, 844-848. https://doi. org/10.1038/nature00812

Cao, M., Zou, X. M., Warren, M., \& Zhu, H. (2006). Tropical forests of Xishuangbanna, China. Biotropica, 38, 306-309. https://doi. org/10.1111/j.1744-7429.2006.00146.x

Clark, D. B., \& Clark, D. A. (1985). Seedling dynamics of a tropical tree impacts of herbivory and meristem damage. Ecology, 66, 1884-1892. https://doi.org/10.2307/2937384

Clay, K., Reinhart, K., Rudgers, J., Tintjer, T., Koslow, J., \& Flory, S. L. (2008). Red Queen Communities. In R. S. Ostfeld, F. Keesing, \& V. T. Eviner (Eds.), Infectious disease ecology: The effects of ecosystems on disease and of disease on ecosystems (pp. 145-178). Princeton, NJ: Princeton University Press.

Coley, P. D., \& Barone, J. A. (1996). Herbivory and plant defenses in tropical forests. Annual Review of Ecology and Systematics, 27, 305-335. https://doi.org/10.1146/annurev.ecolsys.27.1.305

Comita, L. S., \& Engelbrecht, B. M. J. (2009). Seasonal and spatial variation in water availability drive habitat associations in a tropical forest. Ecology, 90, 2755-2765. https://doi.org/10.1890/08-1482.1

Comita, L. S., \& Hubbell, S. P. (2009). Local neighborhood and species' shade tolerance influence survival in a diverse seedling bank. Ecology, 90, 328-334. https://doi.org/10.1890/08-0451.1

Comita, L. S., Queenborough, S. A., Murphy, S. J., Eck, J. L., Xu, K. Y., Krishnadas, M., ... Zhu, Y. (2014). Testing predictions of the JanzenConnell hypothesis: A meta-analysis of experimental evidence for distance- and density-dependent seed and seedling survival. Journal of Ecology, 102, 845-856. https://doi.org/10.1111/1365-2745.12232

Condit, R. (1998). Tropical forest census plots: Methods and results from Barro Colorado Island, Panama and a comparison with other plots. Berlin, Germany: Springer Science \& Business Media. https://doi. org/10.1007/978-3-662-03664-8

Connell, J. H. (1978). Diversity in Tropical rain forests and coral reefs - high diversity of trees and corals is maintained only in a nonequilibrium state. Science, 199, 1302-1310. https://doi.org/10.1126/ science.199.4335.1302

Dobson, A. (2004). Population dynamics of pathogens with multiple host species. American Naturalist, 164, S64-S78. https://doi. org/10.1086/424681

Engelbrecht, B. M., Kursar, T. A., \& Tyree, M. T. (2005). Drought effects on seedling survival in a tropical moist forest. Trees, 19, 312-321. https://doi.org/10.1007/s00468-004-0393-0

Fan, Z.-X., Bräuning, A., Thomas, A., Li, J.-B., \& Cao, K.-F. (2011). Spatial and temporal temperature trends on the Yunnan Plateau (Southwest China) during 1961-2004. International Journal of Climatology, 31, 2078-2090. https://doi.org/10.1002/joc.2214

Fan, Z.-X., \& Thomas, A. (2013). Spatiotemporal variability of reference evapotranspiration and its contributing climatic factors in Yunnan Province, SW China, 1961-2004. Climatic Change, 116, 309-325. https://doi.org/10.1007/s10584-012-0479-4
Gornish, E. S., \& Tylianakis, J. M. (2013). Community shifts under climate change: Mechanisms at multiple scales. American Journal of Botany, 100, 1422-1434. https://doi.org/10.3732/ ajb.1300046

Harms, K. E., Wright, S. J., Calderon, O., Hernandez, A., \& Herre, E. A. (2000). Pervasive density-dependent recruitment enhances seedling diversity in a tropical forest. Nature, 404, 493-495. https://doi. org/10.1038/35006630

Hersh, M. H., Vilgalys, R., \& Clark, J. S. (2011). Evaluating the impacts of multiple generalist fungal pathogens on temperate tree seedling survival. Ecology, 93, 511-520.

Janzen, D. H. (1970). Herbivores and the number of tree species in tropical forests. The American Naturalist, 104, 501-528. https://doi. org/10.1086/282687

Jia, X., Dai, X. F., Shen, Z. X., Zhang, J. Y., \& Wang, G. X. (2011). Facilitation can maintain clustered spatial pattern of plant populations during density-dependent mortality: Insights from a zone-of-influence model. Oikos, 120, 472-480. https://doi. org/10.1111/j.1600-0706.2010.18674.x

Johnson, D. J., Beaulieu, W. T., Bever, J. D., \& Clay, K. (2012). Conspecific negative density dependence and forest diversity. Science, 336, 904907. https://doi.org/10.1126/science.1220269

Johnson, D. J., Bourg, N. A., Howe, R., McShea, W. J., Wolf, A., \& Clay, K. (2014). Conspecific negative density-dependent mortality and the structure of temperate forests. Ecology, 95, 2493-2503. https://doi. org/10.1890/13-2098.1

LaManna, J. A., Mangan, S. A., Alonso, A., Bourg, N. A., Brockelman, W. Y., Bunyavejchewin, S., ... Myers, J. A. (2017). Plant diversity increases with the strength of negative density dependence at the global scale. Science, 356, 1389-1392. https://doi.org/10.1126/ science.aam5678

LaManna, J. A., Walton, M. L., Turner, B. L., \& Myers, J. A. (2016). Negative density dependence is stronger in resource-rich environments and diversifies communities when stronger for common but not rare species. Ecology Letters, 19, 657-667. https://doi. org/10.1111/ele.12603

Lin, L., Comita, L. S., Zheng, Z., \& Cao, M. (2012). Seasonal differentiation in density-dependent seedling survival in a tropical rain forest. Journal of Ecology, 100, 905-914. https://doi.org/10.1111/j.1365-2745.2012.01964.x

Liu, X. B., Liang, M. X., Etienne, R. S., Wang, Y. F., Staehelin, C., \& Yu, S. X. (2012). Experimental evidence for a phylogenetic Janzen-Connell effect in a subtropical forest. Ecology Letters, 15, 111-118. https:// doi.org/10.1111/j.1461-0248.2011.01715.x

Lu, J., Johnson, D. J., Qiao, X., Lu, Z., Wang, Q., \& Jiang, M. (2015). Density dependence and habitat preference shape seedling survival in a subtropical forest in central China. Journal of Plant Ecology, 8, 568-577.

Meinzer, F. C., Andrade, J. L., Goldstein, G., Holbrook, N. M., Cavelier, J., \& Wright, S. J. (1999). Partitioning of soil water among canopy trees in a seasonally dry tropical forest. Oecologia, 121, 293-301. https:// doi.org/10.1007/s004420050931

Metz, M. R., Sousa, W. P., \& Valencia, R. (2010). Widespread densitydependent seedling mortality promotes species coexistence in a highly diverse Amazonian rain forest. Ecology, 91, 3675-3685. https://doi.org/10.1890/08-2323.1

Peters, H. A. (2003). Neighbour-regulated mortality: The influence of positive and negative density dependence on tree populations in species-rich tropical forests. Ecology Letters, 6, 757-765. https://doi. org/10.1046/j.1461-0248.2003.00492.x

Piao, T., Comita, L. S., Jin, G. Z., \& Kim, J. H. (2013). Density dependence across multiple life stages in a temperate old-growth forest of northeast China. Oecologia, 172, 207-217. https://doi.org/10.1007/ s00442-012-2481-y

Record, S., Kobe, R. K., Vriesendorp, C. F., \& Finley, A. O. (2016). Seedling survival responses to conspecific density, soil nutrients, and 
irradiance vary with age in a tropical forest. Ecology, 97, 2406-2415. https://doi.org/10.1002/ecy.1458

Slik, J. W. F. (2004). El Nino droughts and their effects on tree species composition and diversity in tropical rain forests. Oecologia, 141, 114-120. https://doi.org/10.1007/s00442-004-1635-y

Slot, M., \& Poorter, L. (2007). Diversity of tropical tree seedling responses to drought. Biotropica, 39, 683-690. https://doi. org/10.1111/j.1744-7429.2007.00328.x

Spear, E. R., Coley, P. D., \& Kursar, T. A. (2015). Do pathogens limit the distributions of tropical trees across a rainfall gradient? Journal of Ecology, 103, 165-174. https://doi.org/10.1111/1365-2745. 12339

Stoll, P., \& Newberry, D. M. (2005). Evidence of species-specific neighborhood effects in the Dipterocarpaceae of a Bornean rain forest. Ecology, 86, 3048-3062. https://doi.org/10.1890/04-1540

Swinfield, T., Lewis, O. T., Bagchi, R., \& Freckleton, R. P. (2012). Consequences of changing rainfall for fungal pathogen-induced mortality in tropical tree seedlings. Ecology and Evolution, 2, 1408-1413. https://doi.org/10.1002/ece3.252

Valencia, R., Foster, R. B., Villa, G., Condit, R., Svenning, J. C., Hernandez, C., ... Balslev, H. (2004). Tree species distributions and local habitat variation in the Amazon: Large forest plot in eastern Ecuador. Journal of Ecology, 92, 214-229. https://doi. org/10.1111/j.0022-0477.2004.00876.x

Valladares, F., Bastias, C. C., Godoy, O., Granda, E., \& Escudero, A. (2015). Species coexistence in a changing world. Frontiers in Plant Science, 6, 866. PMC4604266.

Vandermeer, J. H. (1972). Niche theory. Annual Review of Ecology and Systematics, 3, 107-132. https://doi.org/10.1146/annurev. es.03.110172.000543

Wright, J. S. (2002). Plant diversity in tropical forests: A review of mechanisms of species coexistence. Oecologia, 130, 1-14. https://doi. org/10.1007/s004420100809

Wu, J., Swenson, N. G., Brown, C., Zhang, C., Yang, J., Ci, X. Q., ... Lin, L. X. (2016). How does habitat filtering affect the detection of conspecific and phylogenetic density dependence? Ecology, 97, 1182-1193. https://doi.org/10.1890/14-2465.1

Xu, M., Wang, Y., Liu, Y., Zhang, Z., \& Yu, S. (2015). Soil-borne pathogens restrict the recruitment of a subtropical tree: a distance-dependent effect Oecologia, 177, 723-732. https://doi.org/ 10.1007/ s00442-014-3128-y

Yanar, Y., Lipps, P. E., \& Deep, I. W. (1997). Effect of soil saturation duration and soil water content on root rot of maize caused by Pythium arrhenomanes. Plant Disease, 81, 475-480. https://doi.org/10.1094/ PDIS.1997.81.5.475

Zhang, Y. H., Wang, Y. F., \& Yu, S. X. (2014). Interspecific Neighbor Interactions Promote the Positive Diversity-Productivity Relationship in Experimental Grassland Communities. PLoS ONE, 9, e111434. https:// doi.org/10.1371/journal.pone.0111434

Zhu, Y., Comita, L. S., Hubbell, S. P., \& Ma, K. (2015). Conspecific and phylogenetic density-dependent survival differs across life stages in a tropical forest. Journal of Ecology, 103, 957-966. https://doi. org/10.1111/1365-2745.12414

\section{SUPPORTING INFORMATION}

Additional supporting information may be found online in the Supporting Information section at the end of the article.

Appendix S1 The sample size of each GLMM model.

How to cite this article: Song X, Johnson DJ, Cao M, et al. The strength of density-dependent mortality is contingent on climate and seedling size. J Veg Sci. 2018;29:662-670.

https://doi.org/10.1111/jvs.12645 